\title{
Isolation and Partial Purification of Polyphenol Oxidase from Seed of Melon (Cucumeropsis edulis)
}

\author{
Catherine Joke Adeseko ${ }^{1, * i D}$, Toluwase Hezekiah Fatoki ${ }^{2}$ \\ 1 Enzymology Unit, Department of Biochemistry, The Federal University of Technology Akure, PMB 704, Akure, Ondo \\ State, Nigeria; catherineadeseko@gmail.com (C.J.A.); \\ 2 Department of Biochemistry, Federal University Oye-Ekiti, PMB 373, Oye-Ekiti, Ekiti State, Nigeria; \\ hezekiahfatoki@gmail.com (T.H.F.); \\ * Correspondence: catherineadeseko@gmail.com;
}

Scopus Author ID 57211491082

Received: 9.07.2020; Revised: 25.08.2020; Accepted: 28.08.2020; Published: 1.09.2020

\begin{abstract}
Polyphenol oxidase (PPO) from Cucumeropsis edulis was extracted and partially purified through (NH4) ${ }_{2} \mathrm{SO}_{4}$ precipitation, dialysis, and ion-exchange chromatography on DEAE-SephadexA50. The spectrophotometric method was used to assay the enzyme activity in C. edulis using L-DOPA as substrate, the physicochemical properties such as the effect of $\mathrm{pH}$ and temperature, substrate specificity, kinetic constants - maximum enzyme velocity $\left(\mathrm{V}_{\max }\right)$, and Michaelis - Menten constant $\left(\mathrm{K}_{\mathrm{m}}\right)$ for three substrates namely, L-Dopa catechol and tyrosine were determined. The effects of inhibitors and metal ions on PPO activity were also investigated. The optimum $\mathrm{pH}$ and temperature values were found to be $\mathrm{pH} 6.5$ and $50{ }^{\circ} \mathrm{C}$, and the inhibitory effects of inhibitors such as ascorbic acid, EDTA, SDS, and metal ions were enhanced positively with increased concentration except with divalent metals such as $\mathrm{Cu}^{2+}, \mathrm{Fe}^{2+}$, and $\mathrm{Zn}^{2+}$ reflecting an activating effect on C. edulis PPO. Moreover, the enzyme solution showed both monophenolase and diphenolase activity with L-DOPA having the highest $\mathrm{V}_{\max } / \mathrm{K}_{\mathrm{m}}$ value. However, the data obtained in this research provided a theoretical basis for the prevention of enzymatic browning of C. edulis during processing.
\end{abstract}

Keywords: Polyphenol oxidase; Cucumeropsis eduli; physicochemical properties; Enzyme activity.

(C) 2020 by the authors. This article is an open-access article distributed under the terms and conditions of the Creative Commons Attribution (CC BY) license (https://creativecommons.org/licenses/by/4.0/).

\section{Introduction}

Cucumeropsis edulis, a member of Cucurbitaceae family, is a variety of melon seeds, which is a creeping and an intercropping plant made use of in traditional farming practices, thrives well on rich light soil in the hot climatic regions of African nations [1-3]. Contrary to the other species of the family of the Cucurbitaceae, C. edulis plant is widely cultivated for their seeds, which have a high content of fat and protein [2]. Nasiru and Oluwasegun [4], Yasar [5], and Falade et al. [6] had earlier investigated the nutritional constituents as well as the effect of processing on the anti-nutrient quantities of Curcubitaceae seeds. The seeds of C. edulis contain proteins and other nutritionally important components that could be harnessed as alternatives for the human diet [3,7]. C. edulis seeds can be obtained either in shelled or unshelled forms in West African Markets and are used greatly in cookery. The seeds of the $C$. edulis present themselves under the whitish color of oval and flat shape. The seeds of the $C$. edulis are part of the condiments used in the preparation of sauces consumed in most African nations [2]. They are consumed crushed or grilled and served to thicken sauces and sometimes make into a cake for its delicacy. In the course of dehulling and crushing or making into 
powder, the color is observed to change from whitish to greyish, making it appears dull and eventually lose its acceptability for market value. Similar to other commercially-available crops, dehulled C. edulis, is prone to browning due to post-harvest effect. Food browning has a critical impact on processed foods as fruits, vegetables, and seeds are susceptible to enzymatic browning, which is typically catalyzed by polyphenol oxidase (PPO) [8- 9]. After harvest, crops are usually subjected to serial post-harvest processing steps that include peeling, slicing, or cutting, crushing to allow efficient storage [9]. Injury can destroy subcellular compartmentalization in plant tissues, releasing endogenous phenolic substrates, and allow PPO to interact with its substrates, thereby causing browning [9-10].

PPO is a family of copper-containing oxidoreductases that are widely distributed among plants in chloroplasts and can catalyze hydroxylation of monophenols to O-diphenols, followed by oxidation of O-diphenols to O-quinones [11-12]. Oxidation products of phenols undergo further condensation reactions to become dark-colored (melanins) on plant surfaces, leading to a high percentage yield loss due to degradation of food quality during post-harvest storage [1314]. Enzymatic browning also results in alteration of physical appearance, adversely affecting color, flavor, nutritional properties, thereby reducing the shelf life of processed food substances. Different preservation methods, such as freezing, canning, and drying are commonly applied to extend the availability of fruits and seeds [15-16]. However, browning remains a problem in $C$. edulis handling and preservation and is believed to be a major factor of quality loss during processing [9].

Characterization of PPO has widely been observed in various plant sources, cocoa bean seeds [17], potato [18], wheat [8], apple [19], African bush mango seeds [12], Sorghum [20], among many others. Information on the isolation of PPO from the seed of C. edulis and its physicochemical properties have not been established based on the available literature around. Therefore, it is necessary to isolate and characterize PPO from C. edulis, in order to proffer effective methods for controlling oxidative browning during the processing of $C$. edulis. In order to achieve this, a detailed biochemical analysis of polyphenol oxidase from C. edulis was conducted to determine its $\mathrm{pH}$ and temperature optimal reaction conditions, kinetic parameters, and the effects of various inhibitors and metal ions on the enzyme activity.

\section{Materials and Methods}

\subsection{Sample preparation.}

Fully matured fruits of $C$. edulis (Egusi Ito) were purchased from a local market in Akure, Ondo State, Nigeria, and identified at the Department of Crop Science and Pest, School of Agriculture, Federal University of Technology, Akure. The seeds were removed, air-dried for two weeks, and later dehulled manually. All chemicals and reagents were analytical grade and purchased from Sigma-Aldrich (St. Louis, MO, USA).

\subsection{Preparation of crude PPO extract.}

Melon seeds $(500 \mathrm{~g}$ ) of C. edulis were thoroughly homogenized in $1.5 \mathrm{~L}$ of ice-cold 25 $\mathrm{mM}$ phosphate buffer ( $\mathrm{pH}$ 6.8) containing $10 \mathrm{mM}$ ascorbic acid using a Saisho warring blender. The homogenate was filtered using a four-layer of cheesecloth. The filtrate was again filtered using glass wool to remove the floating lipid, followed by centrifugation in a cold centrifuge at $16,000 \mathrm{rpm}$ for 30 minutes at $4^{\circ} \mathrm{C}$. The supernatant was kept at $-4^{\circ} \mathrm{C}$ while the lipid layer was separated by removing the enzyme solution using a micropipette and further subjected to 
centrifugation, after which the remaining lipid droplet was removed by passing the solution through glass wool. The supernatant was stored in a refrigerator and used as a crude enzyme for further experiments.

\subsection{Purification of polyphenol oxidase from C. edulis.}

\subsubsection{Ammonium sulfate precipitation.}

The crude enzyme (125 mL) was brought to $80 \%$ ammonium sulfate saturation by slowly adding solid ammonium sulfate at a temperature of $4{ }^{\circ} \mathrm{C}$ using a magnetic stirrer by stirring continuously until all was dissolved. The precipitate was collected by centrifugation at $16,000 \mathrm{rpm}$ for 10 minutes. The precipitate was dissolved in $5 \mathrm{~mL} 0.1 \mathrm{M}$ phosphate buffer $(\mathrm{pH}$ 6.8) and dialyzed with the same buffer at $4{ }^{\circ} \mathrm{C}$ overnight with changes of buffer.

\subsubsection{Ion - exchange chromatography.}

The dialysate was placed on a DEAE - A50 Sephadex column $(3.5 \times 13 \mathrm{~cm})$. The column was pre-equilibrated with $0.1 \mathrm{M}$ Potassium phosphate buffer, $\mathrm{pH} 6.8$, and the protein was eluted using the same buffer (flow rate: $20 \mathrm{~mL} / \mathrm{hr}$ ) were passed through the column. The unbound protein was eluted from the column with starting buffer followed by releasing the bound protein with the use of a linear gradient of 0 to $0.5 \mathrm{M} \mathrm{NaCl}$ in $0.1 \mathrm{M}$ potassium phosphate buffer. The absorbance of the fractions was read at $280 \mathrm{~nm}$, and each fraction was tested for polyphenol oxidase activity while the fractions exhibited polyphenol oxidase activity were pooled together and concentrated with $4 \mathrm{M}$ sucrose and used for characterization.

\subsubsection{Determination of protein concentration.}

Protein concentration was determined according to the method described by Lowry et al. [21] using Bovine serum albumin (BSA) as a standard.

\subsubsection{Determination of polyphenol oxidase activity.}

PPO activity was determined by measuring the increase in absorbance at $420 \mathrm{~nm}$ using catechol as a substrate. The reaction mixture consisted of a $0.2 \mathrm{~mL}$ enzyme solution and 2.8 $\mathrm{mL}$ of $10 \mathrm{mM}$ substrate solution in $25 \mathrm{mM}$ phosphate buffer $\left(\mathrm{pH} \mathrm{6.8)}\right.$, at $25^{\circ} \mathrm{C} \mathrm{[22].} \mathrm{One} \mathrm{unit}$ of PPO activity was defined as the amount of enzyme that caused an increase in absorbance of 0.001 per min.

\subsection{Physicochemical properties of polyphenol oxidase.}

2.4.1. Determination of C. edulis PPO substrate specificity.

Four different substrates (catechol, gallic acid, L-DOPA, and tyrosine) at $10 \mathrm{mM}$ concentration were prepared in $0.1 \mathrm{M}$ phosphate buffer ( $\mathrm{pH}$ 6.8). PPO activity was determined according to the standard assay procedure at a corresponding wavelength $420 \mathrm{~nm}$ (catechol), $270 \mathrm{~nm}$ (gallic acid), 475nm (L-DOPA), and $300 \mathrm{~nm}$ (tyrosine).

\subsubsection{Effect of $\mathrm{pH}$ in the presence and absence of SDS on C. edulis PPO.}

The enzyme $\mathrm{pH}$ optimum was determined with and without SDS, according to Escribano et al. [23], using various buffers at $\mathrm{pH}$ ranges from 2.0 - 9.0. 0.1 M. The reaction 
mixture contained glycine $\mathrm{NaOH}$ buffer ( $\mathrm{pH} 2.0$ - 3.0); 0.1M sodium acetate buffer $(\mathrm{pH} 4.0$ 5.0); 0.1M potassium phosphate buffer ( $\mathrm{pH} 6.0$ - 7.0) and 0.1M tris- HCI buffer ( $\mathrm{pH} 8.0$ - 9.0) in the presence and absence of $0.69 \mathrm{mM}$ SDS. Enzymatic activity was determined according to the standard assay procedure.

\subsection{3. pH stability of C. edulis PPO.}

The $\mathrm{pH}$ stability of the purified PPO was determined according to the method of Escribano et al. [23[ by preparing various buffers of $\mathrm{pH} 2.0-9.0$ using $0.1 \mathrm{M}$ glycine $\mathrm{NaOH}$ ( $\mathrm{pH} 2.0$ - 3.0), sodium acetate buffer ( $\mathrm{pH} 4.0$ - 5.0), potassium phosphate buffer ( $\mathrm{pH} 6.0$ - 7.0) and Tris- HCI buffer ( $\mathrm{pH} 8.0$ - 9.0), and then incubating the purified enzyme with the same buffer solutions for 6 hours. The residual activity was determined by drawing $1 \mathrm{~mL}$ of an aliquot enzyme at a one-hour interval subsequently after initial ( 0 hours) activity according to the standard assay procedure.

\subsubsection{Thermo-stability of C. edulis PPO.}

The effect of temperature on the enzyme activity was investigated by varying the temperature condition between 30 to $80{ }^{\circ} \mathrm{C}$. The reacting mixture consisted of the purified enzyme, and L-DOPA was incubated at the above temperature range, while $1 \mathrm{~mL}$ of the aliquot enzyme was withdrawn at an interval of $10{ }^{\circ} \mathrm{C}$ after 10 minutes. The activity was determined according to the standard assay procedure. The thermal stability was determined by incubating the enzyme at different temperature range $\left(30-80{ }^{\circ} \mathrm{C}\right)$. The initial activity was determined at the 0 minutes, while the residual polyphenol oxidase activity was determined at 10-minute intervals for each temperature according to the standard assay procedure.

\subsubsection{Kinetic parameters of C. edulis PPO.}

The kinetic parameters, $\mathrm{K}_{\mathrm{m}}$ and $\mathrm{V}_{\max }$ of the partially purified enzyme was determined using Lineweaver-Burk [24] plot with catechol, gallic acid, tyrosine, and L-DOPA as substrates, at varying concentrations $(40,35,30,25,20,15,10$, and $5 \mathrm{mM})$ in $0.1 \mathrm{M}$ potassium phosphate buffer ( $\mathrm{pH}$ 6.8).

\subsubsection{Effect of inhibitors and activators on C. edulis PPO Activity.}

Polyphenol oxidase activity was determined in the presence of ascorbic acid, EDTA, urea, and SDS. The assays were carried out at different final concentrations: 5, 10, and $20 \mathrm{mM}$ of the reaction mixture. The activity was measured according to the standard assay procedure.

\subsubsection{Effect of metal ions on C. edulis PPO activity.}

The effect of metal ion at varying concentrations was determined using $\mathrm{Ca}^{2+} \mathrm{Cu}^{2+}$, $\mathrm{Mg}^{2+}, \mathrm{Fe}^{2+} \mathrm{Zn}^{2+}$ and $\mathrm{Na}^{+}$salts at concentration of 5,10 , and $20 \mathrm{mM}$ respectively in $0.1 \mathrm{M}$ potassium phosphate buffer ( $\mathrm{pH}$ 6.8). PPO activity was determined according to the standard assay procedure. 


\section{Results and Discussion}

\subsection{Purification profile of polyphenol oxidase of melon seed (C. edulis).}

Although PPO has been purified and characterized from many plants, there is no any report describing PPO from melon seeds $(C$. eduli). In order to overcome the negative effects of its phenolic substrates on the ionic and hydrophobic characteristics, Polyvinylpolypyrrolidone (PVPP) (5\%) and ascorbic acid (10 mM) were used to bind the phenols and to reduce quinones to phenolic substrates during extraction, respectively. There were several studies on the PPO purification and characterization using only the precipitated fractions of ammonium sulfate without using chromatographic purification methods [25]. The best extraction fraction here was achieved with $80 \%\left(\mathrm{NH}_{4}\right)_{2} \mathrm{SO}_{4}$ saturation at $4{ }^{\circ} \mathrm{C}$, followed by ion-exchange chromatography. Polyphenol oxidase activity was eluted in the fractions with the activity peak from the ion-exchange column, as shown in Figure 1. The specific activity of the partially purified enzyme was $1.64 \mathrm{U} / \mathrm{mg}$; a 16-fold purification of the enzyme was achieved with a $0.4 \%$ yield. The summary of the purification procedure is given in Table 1 .

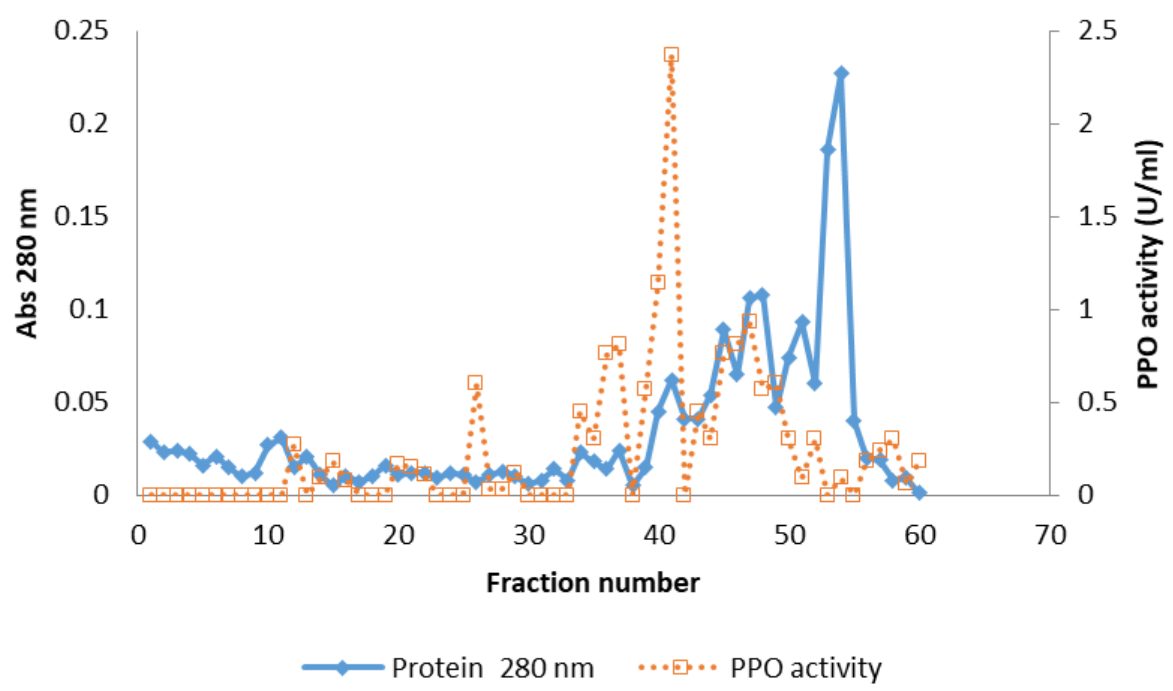

Figure 1. Elution profile of polyphenol oxidase on an ion-exchange column $(3.5 \times 13 \mathrm{~cm})$ of DEAE Sephadex A-50.

\begin{tabular}{|c|c|c|c|c|c|c|c|c|}
\hline Step & $\begin{array}{l}\text { Total } \\
\text { Vol. } \\
(\mathrm{mL}) \\
\end{array}$ & $\begin{array}{l}\text { Protein } \\
\text { concentration } \\
(\mathbf{m g} / \mathbf{m L})\end{array}$ & $\begin{array}{l}\text { Total } \\
\text { protein(mg) }\end{array}$ & $\begin{array}{l}\text { Activity } \\
\text { (U/mL) }\end{array}$ & $\begin{array}{l}\text { Total } \\
\text { Activity } \\
\text { (U) }\end{array}$ & $\begin{array}{l}\text { Specific } \\
\text { Activity } \\
\text { (U/mg) }\end{array}$ & $\begin{array}{l}\text { Purification } \\
\text { fold }\end{array}$ & $\begin{array}{l}\text { Yield } \\
(\%)\end{array}$ \\
\hline Crude enzyme & 750 & 6.5 & 4875 & 0.65 & 487.5 & 0.1 & 1 & 100 \\
\hline $\begin{array}{l}\left(\mathrm{NH}_{4}\right)_{2} \mathrm{SO}_{4} \\
\text { precipitation }\end{array}$ & 125 & 3.2 & 400 & 1.82 & 227.5 & 0.57 & 5.7 & 0.5 \\
\hline $\begin{array}{l}\text { DEAE Sephadex } \\
\text { A -50 }\end{array}$ & 40 & 2.95 & 118 & 4.85 & 194 & 1.64 & 16.4 & 0.4 \\
\hline
\end{tabular}

Total Protein $(\mathrm{mg})=$ Protein concentration $(\mathrm{mg} / \mathrm{ml}) \times$ Total volume $(\mathrm{mL})$

Total Activity $(\mathrm{U})=$ Activity in the fraction $(\mathrm{U} / \mathrm{ml}) \times$ Total volume $(\mathrm{mL})$

Specific Activity $(\mathrm{U} / \mathrm{mg})=$ Total activity $(\mathrm{U}) /$ Total protein $(\mathrm{mg})$

Yield $(\%)=($ Total Activity of Purified step / Total Activity of the crude $) \times 100$

Purification Fold $=($ Specific Activity of Purified Step $/$ Specific Activity of the Crude

\subsection{Effect of $p H$ on C. edulis PPO activity and stability.}

The effect of $\mathrm{pH}$ on the $C$. edulis PPO activity was studied by using $10 \mathrm{mM}$ L-DOPA as substrate at various $\mathrm{pH}$ values at room temperature. The $\mathrm{pH}$ activity profile (Figure 2a) 
indicated that the optimum $\mathrm{pH}$ value for $C$. edulis $\mathrm{PPO}$ activity was 6.5 . This result is similar to Bello et al. [26], who reported optimum pH 6.5 for pumpkin PPO but higher than that of Ferula sp. (6.0) [27] and medlar fruit [28]. The result of $C$. edulis PPO pH stability indicated that the enzyme was stable within $\mathrm{pH}$ 6-7 (Figure 2b), retaining more than $70 \%$ of its activity. On the other hand, the enzyme was almost unstable and inactive at pHs 2.0 and 9.0, with less than $25 \%$ of its residual activity. Collectively, proper $\mathrm{pH}$ value is essential for PPO to achieve maximum activity. It can be concluded that improper $\mathrm{pH}$ value is an efficient way to prevent enzymatic browning [29]. The observed inhibition of PPO in this study by low concentration of SDS is not consistent with generally reported activation of PPO by low concentration of SDS [23]. Kenten [30] has reported that the activation of crude bean leaf PPO by SDS occurred below $1 \mathrm{mM}$ SDS. Though some authors, Moore [31], Jimenez and Garcia- Carmona [32], Escribano et al. [23], Laveda et al. [33], revealed from their experiments the joint effects of $\mathrm{pH}$ and SDS on PPO activity that the detergent causes a shift in the $\mathrm{pH}$ optimum of the enzyme from low to higher $\mathrm{pH}$ values but their reports is at variance with the same optimum $\mathrm{pH}$ observed in the presence and absence of SDS in this study. However, this behavior of a shift in $\mathrm{pH}$ does not seem ubiquitous as similar $\mathrm{pH}$ optimum profiles with and without SDS were obtained for latent potato leaf PPO [34]. Subjecting C. edulis seed to acidic $\mathrm{pH}$ in the presence and absence of SDS could possibly ameliorate its browning effect owing to inhibition PPO activity at this said $\mathrm{pH}$, thereby increasing its quality.

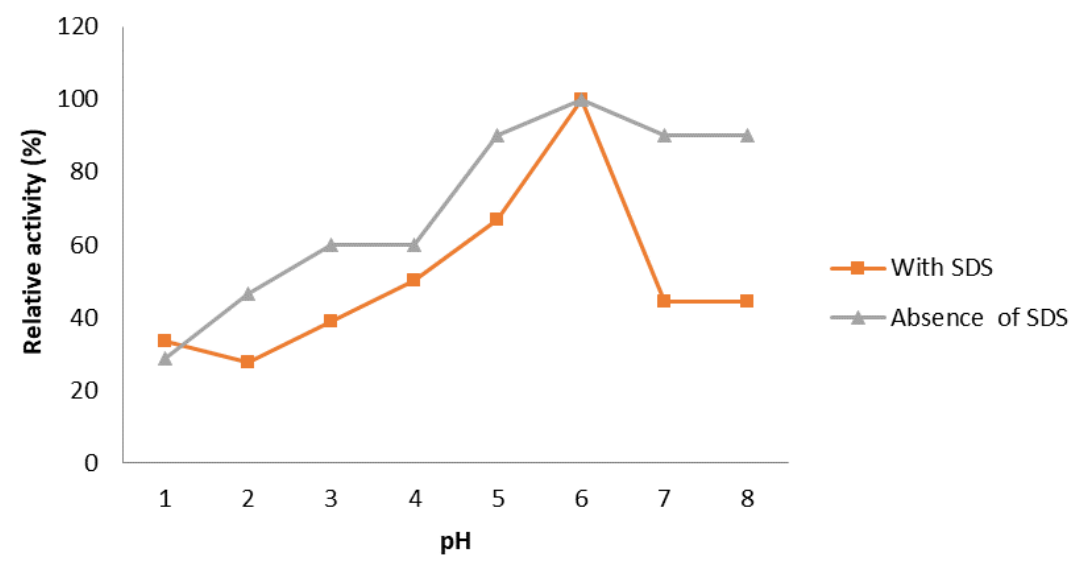

Figure 2(a). Effect of $\mathrm{pH}$ with SDS and without SDS on C. edulis PPO activity.

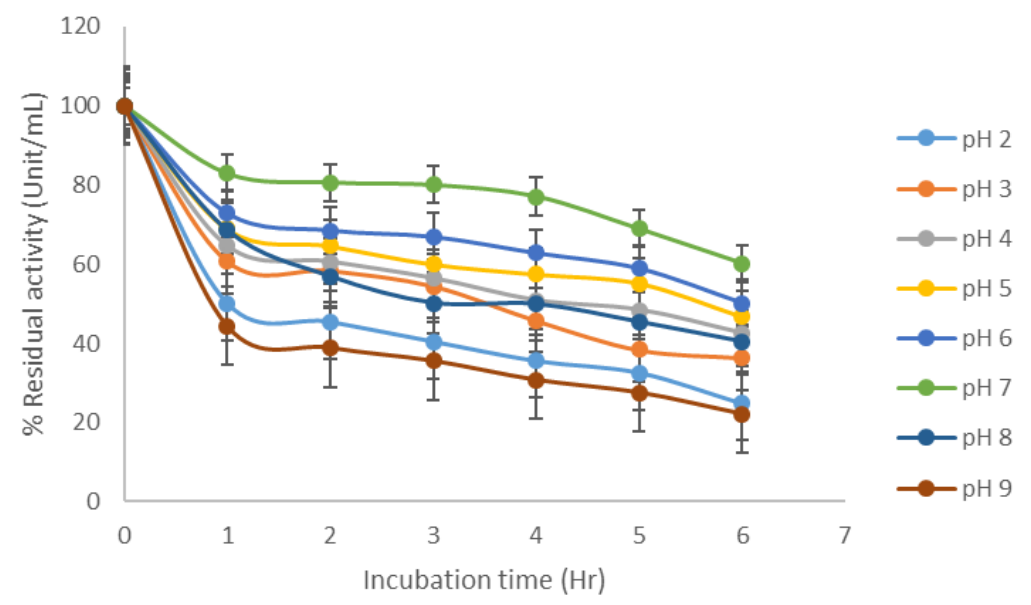

Figure 2(b). pH stability of $C$. edulis PPO. The activity of the enzyme was expressed relative to the activity of the enzyme at $0 \mathrm{~min}$ at $100 \%$ 
3.3. Effect of temperature on C. edulis PPO activity and stability.

The temperature effect on the $C$. edulis PPO activity and stability was studied over a range from 30 to $80^{\circ} \mathrm{C}$ using L-DOPA as substrate. The results are depicted in Figures 3a and $3 \mathrm{~b}$. The enzyme is active from 30 to $55^{\circ} \mathrm{C}$, showing maximum activity at $50{ }^{\circ} \mathrm{C}$. A decrease of C. edulis PPO activity was observed at temperature $>60{ }^{\circ} \mathrm{C}$, and the enzyme lost $30 \%, 50 \%$, and $87 \%$ of its maximal activity at 60,70 , and $80{ }^{\circ} \mathrm{C}$, respectively, until all activity was lost at temperature $>80^{\circ} \mathrm{C}$, due to thermal inactivation.

It has been previously reported that different plants exhibited different optimum temperatures. The optimum temperature of $40^{\circ} \mathrm{C}$ had earlier been reported for dog rose and artichoke PPOs [35,36], respectively, $35^{\circ} \mathrm{C}$ for mamey [37], $25^{\circ} \mathrm{C}$ for Lonicera japonica PPO and $20^{\circ} \mathrm{C}$ for lotus seed [38] using catechol as the substrate. The reported optimum value (50 ${ }^{\circ} \mathrm{C}$ ) in this study is higher than $35^{\circ} \mathrm{C}$ optimum temperature for Capsicum Annuum seeds PPO, which was reported by Guven et al. [39], lower than $60^{\circ} \mathrm{C}$ temperature optima observed in two varieties of Irvingia seed PPOs as reported by Sanni [12]. An optimum temperature $20^{\circ} \mathrm{C}-$ $60{ }^{\circ} \mathrm{C}$ generally observed for various plants using different substrates has been reported by Yoruk and Marshall [40] and Mayer [22] in their views of plant PPOs. However, it should be noted that the optimum temperature of PPO varies in different plant sources and that nature of the substrate influences the optimum temperature.

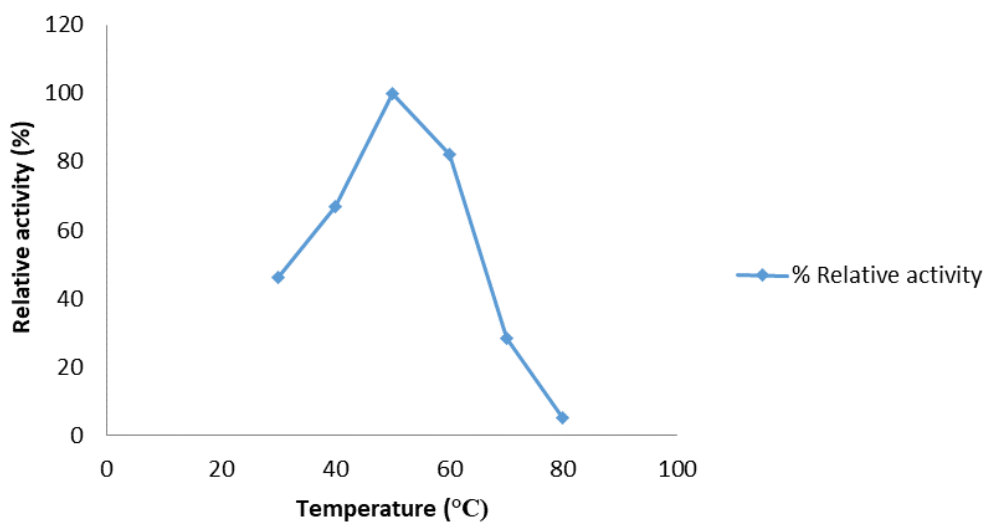

Figure 3(a). Effect of temperature on C. edulis PPO activity.

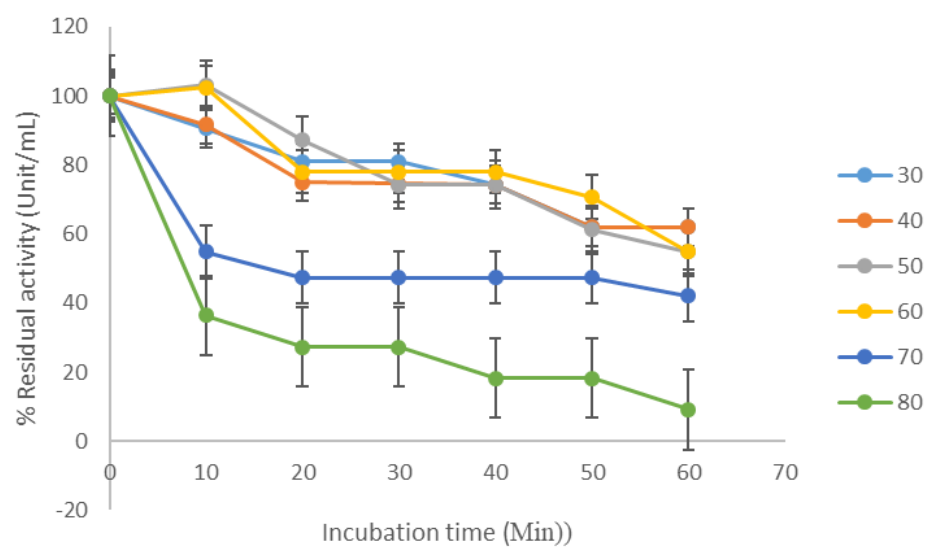

Figure 3(b). Thermal stability of $C$. edulis PPO. The activity of the enzyme was expressed relative to the activity of the enzyme at 0 min taken at $100 \%$.

Insightfully, an appropriate temperature is necessary for the enzyme to achieve the maximum activity. In industrial production, avoiding the proper temperature of the reaction is 
an efficient way to inhibit enzyme activity. The results (Figures $3 a$ and $3 b$ ) showed that the appropriate temperatures to process $C$. edulis were above $60{ }^{\circ} \mathrm{C}$ in view of its PPO activity. Moreover, the curve of temperature-stability indicated that thermal treatment to enzyme inactivation was an essential procedure to prevent enzymatic browning. In summary, the data indicated that heating at high temperature is an effective method to ameliorate the enzymatic browning caused by PPO in C. edulis.

\subsection{Substrate specificity and enzyme kinetics.}

Substrate specificity for $C$. edulis PPO was investigated using 4 different substrates (Table 2) at the enzyme's pH optimum for L-DOPA as the substrate ( $\mathrm{pH}$ 7.0). Activities were compared with the activity observed in the presence of L-DOPA (set as 100\%). The highest activity was found using L-DOPA, followed by gallic acid, catechol, and tyrosine. C. edulis showed activity in all the substrate investigated, but a lower activity toward tyrosine (monophenol) was recorded. The slight monophenolase activity reported for C. edulis PPO suggests that $C$. edulis PPO has a weak activity on monophenols compared to the strong activity on diphenols. Furthermore, a reliable determination of monophenolase activity requires the use of a large amount of enzyme and a substantially extended monitoring time [41]. The results obtained in this study are in agreement with Sanni [12], who reported a higher activity of Irvingia gaboneniss and Irvingia wombolu seed PPOs using L-DOPA as the substrate.

Table 2. Substrate specificity of C. edulis PPO.

\begin{tabular}{l|l} 
Substrate & \% Relative activity \\
\hline L-DOPA & $100 \pm 0$ \\
\hline Gallic acid & $66.5 \pm 9.87$ \\
\hline Catechol & $63.3 \pm 4.85$ \\
\hline Tyrosine & $19.1 \pm 5.56$
\end{tabular}

Data represent the mean \pm standard deviation of replicate readings $(n=3)$

\subsection{Kinetic parameters.}

$\mathrm{K}_{\mathrm{m}}$ and $\mathrm{V}_{\max }$ values for $C$. edulis $\mathrm{PPO}$ for three substrates are presented in Table 3. The affinity of the enzyme varied depending on the substrate used. C. edulis PPO had a higher affinity for L-DOPA, as evidenced by lower $K_{m}$ value and higher $V_{\max }$. The criterion for the best substrate is the $\mathrm{V}_{\max } / \mathrm{K}_{\mathrm{m}}$ ratio, which was recorded higher in L-DOPA. Of the substrates tested, the best substrate for $C$. edulis PPO was L-DOPA. The result of this study compared well with Saedian [42], who reported $\mathrm{K}_{\mathrm{m}}$ value $(8.5 \mathrm{mM})$ for Solanum lycopersicum PPO using L-DOPA as the substrate.

Table 3. Kinetic parameters of $C$. edulis PPO.

\begin{tabular}{l|l|l|l} 
Substrate & $\mathbf{K}_{\mathbf{m}}(\mathbf{m M})$ & $\mathbf{V}_{\max }(\mathbf{U n i t} / \mathbf{m i n})$ & $\begin{array}{l}\mathbf{V}_{\mathbf{m a x}} / \mathbf{K}_{\mathbf{m}}\left(\mathbf{U n i t} / \mathbf{m i n} \mathbf{m} \mathbf{M}^{-}\right. \\
\mathbf{1})\end{array}$ \\
\hline L-DOPA & 3.64 & 0.92 & $2.53 \times 10^{-1}$ \\
\hline Gallic acid & 5.03 & 0.58 & $1.15 \times 10^{-1}$ \\
\hline Catechol & 5.06 & 0.55 & $1.09 \times 10^{-1}$ \\
\hline $\begin{array}{l}\text { Tyrosine } \\
\text { Data represent the mean } \pm \text { standard deviation of replicate readings }(\mathrm{n}=3)\end{array}$
\end{tabular}

\subsection{Effect of inhibitors and metal ions on enzyme activity.}

The effects of inhibitors such as ascorbic acid, EDTA, SDS, and urea (5-20 mM) on C. edulis PPO activity in a concentration-dependent manner were studied. The effects of 
various metal ions $\left(\mathrm{CuSO}_{4}, \mathrm{ZnSO}_{4}, \mathrm{MgSO}_{4}, \mathrm{CaCl}_{2}, \mathrm{FeSO}_{4}, \mathrm{CaCl}_{2}\right.$, and $\left.\mathrm{NaCl}\right)$ on enzyme activity were also investigated with varying concentrations of metal ions, $5 \mathrm{mM}, 10 \mathrm{mM}$, and $20 \mathrm{mM}$ respectively. The enzymatic activity of the control mixture without inhibitors and metal ions was taken as $100 \%$ and then compared to the other treatments.

The presence of chemicals on C. edulis PPO activity assay showed diverse effects. As presented in Tables 4 and 5, the percentage inhibition was compared with that of the control. The percentage (\%) residual enzyme activity with $\mathrm{NaCl}$ and $\mathrm{CaCl}_{2}$ suggests that $\mathrm{Na}^{+}, \mathrm{Ca}^{2+} \mathrm{Cl}^{-}$ showed an inhibitory effect on $C$. edulis PPO activity. Similar results were reported for Victoria grape PPO [43]. Among the divalent cations tested, $\mathrm{Cu}^{2+}$, had a positive effect on $C$. edulis PPO activity at a salt concentration above $10 \mathrm{mM}$. Enzyme activity increases with an increase in the concentration of metals. The effect of ions is highly variable according to enzyme sources [40]. For example, $\mathrm{Zn}^{2+}$ and $\mathrm{Fe}^{2+}$ and $\mathrm{Mg}^{2+}$ at the concentration of $5-10 \mathrm{mM}$ showed a slightly negative effect on $C$. edulis PPO. In contrast, for higher concentrations (20 mM) it stimulated C. edulis PPO activity. Several common PPO inhibitors had an inhibitory effect on the C. edulis PPO. Among these inhibitors, Urea, SDS, EDTA, and Ascorbic acid presented no potent effect at concentrations of $5 \mathrm{mM}$. However, their deactivating effects increased with an increased concentration of $10 \mathrm{mM}$ and above.

Table 4. Effect of Inhibitors on the activity of $C$. edulis PPO.

\begin{tabular}{l|l|l|l}
\multirow{2}{*}{ Inhibitors } & \multicolumn{3}{|c}{ Relative activity (\%) } \\
\cline { 2 - 4 } Ascorbic acid & $\mathbf{5 ~ m M}$ & $\mathbf{1 0 ~} \mathbf{~ m M}$ & $\mathbf{2 0 ~} \mathbf{~ m M}$ \\
\hline EDTA & $70.0 \pm 6.9$ & $32.5 \pm 2.12$ & $17.5 \pm 1.25$ \\
\hline SDS & $75.0 \pm 9.04$ & $55.0 \pm 3.39$ & $17.5 \pm 0.95$ \\
\hline Urea & $38.3 \pm 2.75$ & $17.5 \pm 1.65$ & $7.5 \pm 0.29$ \\
\hline
\end{tabular}

EDTA= Ethylenediaminetetraacetate, $\mathbf{S D S}=$ Sodium dodecyl sulphate.

Data represent the mean \pm standard deviation of replicate readings $(n=3)$

Table 5. Effect of metal ions on activity $C$. edulis PPO.

\begin{tabular}{l|c|c|c}
\multirow{2}{*}{ Salt } & \multicolumn{3}{|c}{ Relative activity $(\mathbf{\%})$} \\
\cline { 2 - 4 } & $\mathbf{5 ~ m M}$ & $\mathbf{1 0} \mathbf{~ m M}$ & $\mathbf{2 0} \mathbf{~ m M}$ \\
\hline $\mathbf{C u S O}_{4}$ & $35.2 \pm 1.62$ & $63.5 \pm 3.62$ & $77.8 \pm 6.35$ \\
\hline FeSO$_{4}$ & $33.3 \pm 1.96$ & $53.7 \pm 1.89$ & $58.2 \pm 1.69$ \\
\hline $\mathbf{Z n S O}_{4}$ & $29.6 \pm 0.95$ & $46.3 \pm 1.89$ & $70.4 \pm 2.68$ \\
\hline $\mathbf{M g S O}_{4}$ & $42.6 \pm 2.95$ & $50.0 \pm 6.73$ & $68.5 \pm 4.55$ \\
\hline $\mathbf{N a C l}_{\mathbf{C a C l}}$ & $25.9 \pm 5.6$ & $16.7 \pm 0.65$ & $5.62 \pm 0.75$ \\
\hline \multicolumn{2}{c}{ Data represent the mean \pm standard deviation of replicate readings $(\mathrm{n}=3)$}
\end{tabular}

The results here are in agreement with Guven et al. [39], who reported EDTA, SDS, and Ascorbic acid showing a deactivating effect on Capsicum annuum seeds PPO. Ascorbic acid exhibited nearly complete inhibition of $C$. edulis PPO at $20 \mathrm{mM}$, and it may act more as an antioxidant than as an enzyme inhibitor. This is consistent with the earlier studies of Gonzalez et al. [44] and Shrestha et al. [45], who reported ascorbic acid as the most potent natural anti-browning agent. Ascorbic acid reduced the initial quinone formation before it undergoes secondary reactions leading to browning [46-47].

\section{Conclusions}

This study reported the partial purification and the characterization of PPO from the seeds of melon for the first time. The optimal $\mathrm{pH}$ and temperature values of 6.5 and $50{ }^{\circ} \mathrm{C}$ were obtained for C. edulis PPO. The result of the kinetic parameters indicated PPO had the highest affinity for L-DOPA, and it was found that L-DOPA was the most efficient phenolic substrate 
for $C$. edulis PPO when considering the ratio of $\mathrm{V}_{\max } / \mathrm{K}_{\mathrm{m}}$. The result was consistent with the previous reports that most plant PPOs exhibit a high affinity for L-DOPA as substrate [40; 48]. The PPO activity was strongly inactivated by ascorbic acid and SDS. This study reveals possible treatments that can be implemented to ameliorate the browning effect of PPO during the processing of melon seeds for human consumption and market values. However, further research is needed to determine inherent enzyme characteristics and propose more edible inhibitors applicable at the industrial scale.

\section{Funding}

This research received no external funding.

\section{Acknowledgments}

This research has no acknowledgment.

\section{Conflicts of Interest}

The authors declare no conflict of interest.

\section{References}

1. Chomicki, G.; Schaefer, H.; Renner, S.S. Origin and domestication of Cucurbitaceae crops: insights from phylogenies, genomics and archaeology. New Phytologist 2020, 226, 1240-1255, https://.doi.org/10.1111/nph.16015.

2. Olubi, O.; Felix-Minnaar, J.V.; Jideani, V.A. Physicochemical and fatty acid profile of egusi oil from supercritical carbon dioxide extraction. Heliyon 2019, 5, https://doi.org/10.1016/j.heliyon.2018.e01083.

3. Steiner-Asiedu, M.; Nuro-Ameyaw, P.; Agbemafle, I.; Hammond, H.S.; Tano-Debrah, K. Nutrient Composition and Protein Quality of Four Species of the Curcubitaceae Family.Advance Journal of Food Science and Technology 2014, 6, 843-851, https://.doi.org/10.19026/ajfst.6.122.

4. Yaşar, F. Comparision of fuel properties of biodiesel fuels produced from different oils to determine the most suitable feedstock type. Fuel 2020, 264, https://doi.org/10.1016/j.fuel.2019.116817.

5. Hairudin, A.A.; Tobib, H.M.; Fariza, Z. The performance of a single-cylinder diesel engine fuelled with egusi based biodiesel. IOP Conf Ser Mater Sci Eng 2019, 469, https://doi.org/10.1088/1757899X/469/1/012045.

6. Falade, O.S.; Otemuyiwa, I.O.; Adekunle, A.S. Nutrient composition of watermelon (Citrullis lanatus (Thunb.) Matsum \& Nakai) and egusi melon (Citrullus colocynthis (L) Schrad.) seeds. Agric Conspec Sci 2020, 85, 43-49.

7. Akubor, P.; Obasi, B. Evaluation of the quality of a beverage prepared from toasted melon seeds. South Asian Journal of Food Technology and Environment 2019, 05, 763-770, https://doi.org/10.46370/sajfte.2019.v05i01.02.

8. Taranto, F.; Delvecchio, L.N.; Mangini, G.; Del Faro, L.; Blanco, A.; Pasqualone, A. Molecular and physicochemical evaluation of enzymatic browning of whole meal and dough in a collection of tetraploid wheats. Journal of Cereal Science 2012, 55, 405-414, https://doi.org/10.1016/j.jcs.2012.02.005.

9. Adeseko, C.J.; Sanni, D.M.; Salawu, S.O.; Kade, I.J.; Fatoki, H.T. HPLC-UV Standard Phenolic Constituents of African Bush Mango (Irvingia gabonensis) and Molecular Docking on Polyphenol Oxidases. Journal of Applied Life Sciences International 2019, 22, 1-11, https://doi.org/10.9734/jalsi/2019/v22i130119.

10. Murtaza, A.; Iqbal, A.; Marszałek, K.; Iqbal, M.A.; Waseem Ali, S.; Xu, X.; Pan, S.; Hu, W. Enzymatic, Phyto-, and Physicochemical Evaluation of Apple Juice under High-Pressure Carbon Dioxide and Thermal Processing. Foods 2020, 9, https:/.doi.org/10.3390/foods9020243.

11. Hutabarat, O.S.; Halbwirth, H. Polyphenol oxidase and peroxidase activity in apple: dependency on cultivar and fruit processing. IOP Conference Series: Earth and Environmental Science 2019, 355, https://.doi.org/10.1088/1755-1315/355/1/012106.

12. Sanni, D. Isolation, Partial Purification and Characterization of Polyphenol Oxidase from Two Species of African Mango Seeds ( Irvingia gabonensis and Irvingia wombolu ). Advances in Biochemistry 2016, 4, 4752. 
13. Perumal, A.; Naidu Krishna, S.B.; Sershen, Pillay, K.; Govender, P. Pytochemical composition and biological investigation of Trichilia emetic Vahl. Seed extracts. Letters in Aplied NanoBioscience 2020, 9 , 1111-1116, https://doi.org/10.33263/lianbs92.11111116.

14. Guven, R. G.; Guven, K.S.; bekler, F. M.; Acer, O.; Alkan, H.; Dogru, M. Purification and Characterization of polyphenol oxidase from purslane. Food Science and Technology 2017, 37, 356-362. https://doi.org/10.1590/1678-457x.03216.

15. Pan, Y.; Chen, L.; Pang, L.; Chen, X.; Jia, X.; Li, X. Ultrasound treatment inhibits browning and improves antioxidant capacity of fresh-cut sweet potato during cold storage. RSC Advances 2020, 10, 9193-9202, https://.doi.org/10.1039/C9RA06418D.

16. Han, Q.Y.; Liu, F.; Li, M.; Wang, K.L.; Ni, Y.Y. Comparison of biochemical properties of membrane-bound and soluble polyphenol oxidase from Granny Smith apple (Malus $\times$ domestica Borkh.). Food Chemistry 2019, 289, 657-663, https://doi.org/10.1016/j.foodchem.2019.02.064.

17. Toro-Uribe, S.; Godoy-Chivatá, J.; Villamizar-Jaimes, A.R.; Perea-Flores, M.D.; López-Giraldo, L.J. Insight of Polyphenol Oxidase Enzyme Inhibition and Total Polyphenol Recovery from Cocoa Beans. Antioxidants 2020, 9, https://.doi.org/10.3390/antiox9060458.

18. Almeida, S.L.; Morais, M.A.S.; Albuquerque, J.T.; Barros, A.P.; Simões, A.D; Fonseca, K.S. Polyphenol oxidase and Peroxidase Enzyme Assays In Sweet Potato Cultivars Harvested at Different Times. Rev. Caatinga, Mossoró 2019, 32, 537-542, https://.doi.org/10.1590/1983-21252019v32n226rc.

19. Adeyemi, O.S.; Ladipo, O.; Adeyanju, A.A.; Awakan, O.J.; Otohinoyi, D.A.; Otuechere, C.A. Gallotannin and Annuna muricata extract inhibit polyphenol oxidase activity mitigate browning in Malus domestica. EurAsian Journal of Biosciences. 2019, 13, 35-39.

20. Toluwase Hezekiah, F.; David Morakinyo, S. Physicochemical properties, kinetics and thermodynamic studies of polyphenol oxidase from sorghum (Sorghum bicolor (L.) Moench) for potential use in industry. Nova Biotechnologica et Chimica 2019, 18, 102-117, https://.doi.org/10.2478/nbec-2019-0013.

21. Lowry, O.; Rosenbrough, N.; Farr, A.; Randall, R.J.T.J.o.B.C. Protein measurment Folin with the fend reagent. 1951, 193, 256-267, https://.doi.org/10.10007/978-1-59745-198-72.

22. Mayer, A.M. Polyphenol oxidases in plants and fungi: Going places? A review. Phytochemistry 2006, 67, 2318-2331, https://.doi.org/10.1016/j.phytochem.2006.08.006.

23. Escribano, J.; Cabanes, J.; Garciia-Carmona, F. Characterisation of Latent Polyphenol Oxidase in Table Beet: Effect of Sodium Dodecyl Sulphate. Journal of the Science of Food and Agriculture 1997, 73, 34-38.

24. Lineweaver, H.; Burk, D. Determination of enzyme dissociation constants. Journal of the American Chemical Society 1934, 56,658-660, https://.doi.org/10.1007/BF00446501.

25. Mishra, B. B.; Gautam, S.; Sharma, A. Purification and characterization of polyphenol oxidase (PPO) from eggplant (Solanum melongena). Food Chemistry 2012, 134, 1855-1861. https://doi.org/10.4314/ajtcom.v/oi3.1

26. Bello, A.B.; Sule, M.; Alhassan, A.J. Optimum pH and pH Stability of Crude Polyphenol Oxidase (PPO) Extracted from Five Fruit Samples Commonly Consumed in Kano State, Nigeria. Bayero Journal of Pure and Applied Sciences 2011, 4, 26-31.

27. Erat, M.; Sakiroglu, H.; Kufrevioglu, O.I. Purification and characterization of polyphenol oxidase from Ferula sp. Food Chemistry 2006, 95, 503-508, https://doi.org/10.1016/j.foodchem.2005.01.044.

28. Dincer, B.; Colak, A.; Aydin, N.; Kadioglu, A.; Güner, S. Characterization of polyphenoloxidase from medlar fruits (Mespilus germanica L., Rosaceae). Food Chemistry 2002, 77, 1-7, https://doi.org/10.1016/S0308-8146(01)00359-4.

29. Liu, N.N.; Liu, W.; Wang, D.J.; Zhou, Y.B.; Lin, X.J.; Wang, X.; Li, S.B. Purification and partial characterization of polyphenol oxidase from the flower buds of Lonicera japonica. Food Chemistry 2013, 138, 478-483, https://doi.org/10.1016/j.foodchem.2013.02.028.

30. Kenten, R.H. Latent phenolase in extracts of broad-bean (Vicia faba L.) leaves. I. Activation by acid and alkali. The Biochemical journal 1957, 67, 300-307, https://doi.org/10.1042/bj0670300.

31. Moore, B.M.; Flurkey, W.H. Sodium dodecyl sulfate activation of a plant polyphenoloxidase. Effect of sodium dodecyl sulfate on enzymatic and physical characteristics of purified broad bean polyphenoloxidase. J Biol Chem 1990, 265, 4982-4988.

32. Jiménez, M.; García-Carmona, F. The effect of sodium dodecyl sulphate on polyphenol oxidase. Phytochemistry 1996, 42, 1503-1509, https://doi.org/10.1016/0031-9422(96)00175-6.

33. Laveda, F.; Núñez-Delicado, E.; García-Carmona, F.; Sánchez-Ferrer, A. Reversible Sodium Dodecyl Sulfate Activation of Latent Peach Polyphenol Oxidase by Cyclodextrins. Archives of Biochemistry and Biophysics 2000, 379, 1-6, https://doi.org/10.1006/abbi.2000.1838.

34. Sanchez-Ferrer, A.; Laveda, F.; Garcia-Carmona, F. Partial purification of soluble potato polyphenol oxidase by partitioning in aqueous two-phase system. Journal of Agriculture and Food Chemistry 1993, 41, 12191224, https://doi.org/10.4172/2329-6674.1000141.

35. Sakiroglu, H.; Kufrevioglu, O.I.; Kocacaliskan, I.; Oktay, M.; Onganer, Y. Purification and Characterization of Dog-rose (Rosa dumlis Rechst.) polyphenol oxidase. Journal of Agriculture and Food Chemistry 1996, 44, https://doi.org/10.1021/jf950808g. 
36. Dogan, S.; Turan, Y.; Erturk, H.; Arslan, O. Characterization and Purification of polyphenol oxidase from artichoke (Cynara scolymus L.). Journal of Agriculture and Food Chemistry 2005, 53, 776-785, https://doi.org/10.1021/jf051646j.

37. Palma-Orozco, G.; Ortiz-Moreno, A.; Dorantes-Álvarez, L.; Sampedro, J.G.; Nájera, H. Purification and partial biochemical characterization of polyphenol oxidase from mamey (Pouteria sapota). Phytochemistry 2011, 72, 82-88, https://doi.org/10.1016/j.phytochem.2010.10.011.

38. Cai, X.X.; Hong, Y.X.; Wang, S.Y; Zhao, L.; Na Rao, P.F. Purification and enzymatic characteristics of a novel polyphenol oxidase from lotus seed (Nelumbo nucifera Gaertn. International Journal of Food Science and Technology 2015, 50, 1026-1032, https://doi.org/10.17221/384/2014-CFS.

39. Guven, G.R.; Guler, C.; Guven, K.; Bekler, M.F. Purification and characterization of polyphenol oxidase from purslane \%J Food Science and Technology. 2017, 37, 356-362, https://doi.org/10.1590/1678457x.03216.

40. Yoruk, R.; Marshall, M. R. Physicochemical properties and function of plant polyphenol oxidase:A review. Journal of Food Biochemistry 2003, 27, 361-422, https://doi.org/10.1111/j.1745-4514.2003.tb00289.x.

41. Derardja, A.E.; Pretzler, M.; Kampatsikas, I.; Barkat, M.; Rompel, A. Purification and Characterization of Latent Polyphenol Oxidase from Apricot (Prunus armeniaca L.). Journal of Agriculture and Food Chemistry 2017, 65, 8203-8212, https://doi.org/10.1021/acs.jafc.7b03210.

42. Saeidian, S. Partial purification and characterization of polyphenol oxidase from tomatoes (solanum lycopersicum). International journal of Advanced Biological and BiomedicalResearch 2013, 1, 637-648, https://doi.org/10.21123/bsj.2016.13.3.0469.

43. Rapeanu, G.; Loey, A.V.; Smout, C.; Hendrickx, M. Biochemical characterization and process stability of polyphenol oxidase extracted from Victoria grape (Vitis vinifera ssp.Sativa). Food Chemistry 2006, 94, 253361. https://doi.org/10.1016/j.foodchem.2004.10.058.

44. Gonzalez, M.N.; Massa, G.A.; Helle, M.A.; Olsson, T.N.; Leonardo, A.F., Andrea, S.C., PerHofvander, D.O.; Sergio, E.F. Natural Antibrowning Agents against Polyphenol oxidase Activity in Annona muricata. Journal of Chemistry 2020, 6, https://doi.org/10.1155/2020/1904798.

45. Shrestha, L.; Kulig, B.; Moscetti, R.; Massantini, R.; Pawelzik, E.; Hensel, O.; Sturm, B. Optimisation of Physical and Chemical Treatments to Control Browning Development and Enzymatic Activity on Fresh-cut Apple Slices. Foods 2020, 9, https://doi.org/10.3390/foods9010076.

46. Gawlik-Dziki, U.; Szymanowska, U.; Baraniak, B. Characterization of polyphenol oxidase from broccoli (Brassica oleracea var. botrytis italica) florets. Food Chemistry 2007, 105, 1047-1053, https://doi.org/10.1016/j.foodchem.2007.05.012.

47. Derardja, A. Inhibition of Apricot polyphenol oxidase by combinations of plant proteases and ascorbic acid. Food Chemistry 2019, 4, https://doi.org/10.1016/j.fochx.2019.100053.

48. Kampatsikas, L.; Bijelic, A.; Rompel, A. Biochemical and structural Characterization of tomato polyphenol oxidases provide novel insights into their substrate specificity. Scientific reports 2019, 9, https://doi.org/10.1038/s41598-019-39687-0. 